ADALAH : Buletin Hukum \&

Keadilan

Buletin Hukum \& Keadilan

@adalahuinjkt

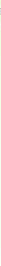

A Salman Maggalatung*

Baru saja kita menyaksikan pesta demokrasi di berbagai daerah provinsi dan kabupaten/kota di Indonesia atau yang disebut dengan Pilkada serentak. Sejatinya Pilkada merupakan ajang pergantian kekuasaan berlangsung secara damai dan bermartabat. Namun kenyataannya di beberapa daerah tertentu justru menjadi ajang adu otot dan adu mulut yang tentunya mencederai demokrasi. Terlihat dari adanya kerusuhan yang terjadi di beberapa daerah seperti pada propinsi papua yang mengakibatkan tewasnya petugas pemilu dan beberapa orang warga masyarakat (www.bbc.com, 28/6/2018). Penandatanganan fakta integritas siap menang dan siap kalah, pada realitanya ternyata hanyalah simbol belaka. Karena pada saat mengalami kekalahan, kubu yang kalah tidak terima dan menuntut pihak yang menang. Sehingga menimbulkan kekisruhan dan kegaduhan politik di sana sini. Oleh karenanya, para kandidat yang berkompetisi mestinya memiliki etika berdemokrasi dan lebih mengedepankan pola politik santun dan damai. Sehingga para pendukung tidak terprovokasi untuk melakukan tindakan anarkis dan kekerasaan.

Indonesia sebagai negara hukum yang demokratis memang tidak menafikkan adanya penyelenggaraan Pemilu, karena pemilu

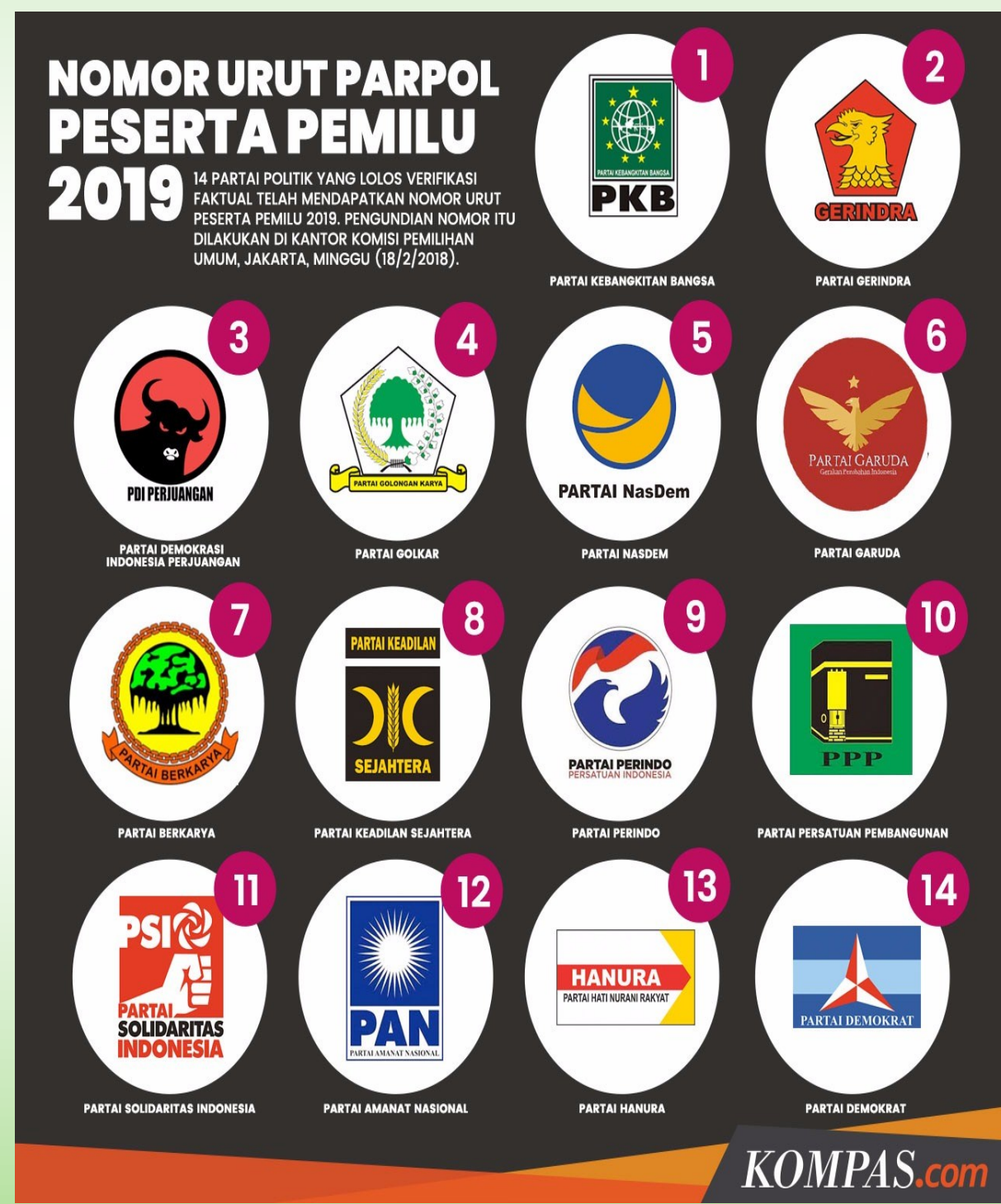

merupakan bagian dari pelaksanaan prinsip demokrasi, dimana rakyat dapat memilih pemimpin negara atau wakil-wakilnya yang berhak membuat suatu kebijakan berdasarkan kehendak rakyat yang digariskan oleh pemimpin negara atau wakil-wakil rakyat tersebut.
(Syahuri, 2011: 155). Selain hakikat pemilu sebagai sarana demokrasi yang intinya untuk menyelenggarakan suatu pemerintahan negara oleh, dari, dan untuk rakyat, atau dengan kata lain mewujudkan kedaulatan yang berada di tangan rakyat dalam bingkai negara hukum 
yang bersifat demokratis (Subhi, 2015: 340).

Harapannya, para politisi hendaklah menjadi petarung-petarung yang gagah dan berani, namun tetap santun dan beretika. Jika menang jadilah pemenang yang baik, jauh dari sifat sombong dan angkuh, secepat mungkin merangkul semua pihak agar rekonsiliasi segera tercipta. Sementara yang kalah terimalah kekalahan itu dengan mengagumi keunggulan lawan, menyadari kelemahan dan kekurangan diri sendiri. Begitupun para pendukung, harus mampu mengedepankan keamanan dan ketentraman Bersama untuk kepentingan bersama. Adapun bagi yang tidak mendampingi sebagai wakilnya. Sementara calon penantangnya masih disibukkan dengan silaturahim dan safari politik ke partai politik dan ormas-ormas kemasyarakatan serta tokoh-tokoh masyarakat. Kita bangsa Indonesia yang memiliki kewajiban memilih, dari sekarang harus sudah pasang niat sambil mencermati visi-misi dan program kerja yang ditawarkan. Sehingga tidak mudah terpengaruh bujuk rayu dan godaan para kandidat untuk menentukan pilihan yang disodorkan oleh parpol pengusung. Patut diketahui bahwa kesuksesan sebuah pemilu tidak hanya diukur dari penyelenggaraan pemilu itu berlangsung dengan lancar, jujur, adil dan rahasia saja, akan tetapi lebih dari itu, kesuksesan sebuah pemilu harus bisa meningkatkan kualitas hasil dari pemilu itu sendiri; yakni dengan lahirnya tokoh-tokoh terbaik bangsa yang tentu saja dapat menjadi uswatun hasanah, cerdas, tidak penakut, teguh memperjuangkan keadilan dan kebenaran, memperkokoh jati diri dan martabat bangsa, mempertinggi mutu dan menghargai kualitas Sumber Daya Manusia serta meningkatkan kesejahteraan orang banyak. Ini yang diharapkan. Selamat menanti. [] puas atas hasil pemilu, maka dapat mengajukan gugatan ke Lembaga Mahkamah Konstitusi. Sehingga keadilan dan kepastian hukum dapat tercipta Bersama.

Tahun 2019 nanti, kita akan menghadapi hajat akbar, hajat nasional, dan hajat kita semua sebagai anak bangsa, yakni pesta demokrasi memilih putra terbaik menjadi orang nomor satu dan dua di negeri ini, yakni memilih Presiden dan wakil Presiden, serta anggota legislatif terhormat di Senayan sana. Saat ini Presiden Jokowi dapat dipastikan akan tampil sebagai kandidat calon Presiden untuk masa jabatan kedua kalinya dan telah mengantongi beberapa nama untuk

\section{Pustaka Acuan:}

*Penulis adalah Guru Besar UIN Syarif Hidayatullah Jakarta pada bidang Hukum Tata Negara.

Subhi, Ahmad Farhan. "Pengusulan Pasangan Calon Presiden dan Wakil Presiden Sebagai Peserta Pemilu Menurut Undang-Undang Pilpres", dalam Jurnal Cita Hukum. Vol. 3 No. 2 Desember (2015).

Syahuri, Taufiqurrohman, Tafsir Konstitusi Berbagai Aspek Hukum, (Jakarta: Kencana Prenada Media Group, 2011).

https://www.bbc.com/indonesia/indonesia-44642737

'Adalah; Buletin Hukum dan Keadilan merupakan berkala ilmiah yang diterbitkan oleh Pusat Studi Konstitusi dan Legislasi Nasional (POSKO-LEGNAS), Fakultas Syariah dan Hukum UIN Syarif Hidayatullah Jakarta.

Penasehat: Prof. Dr. H. Abdul Ghani Abdullah, SH., Prof. Dr. H. A Salman Maggalatung, SH., MH. Pemimpin Redaktur: Indra Rahmatullah, Tim Redaktur: Nurrohim Yunus, Fathuddin, Mara Sutan Rambe, Muhammad Ishar Helmi, Erwin Hikmatiar. Penyunting: Latipah, Siti Nurhalimah. Setting \& Layout: Siti Romlah 